\title{
USE OF PROJECT MANAGEMENT SOFTWARE BY NGO'S AND ITS IMPACT ON EMPLOYEE EFFICIENCY
}

\author{
MEGHNA BHARADWAJ ${ }^{\mathbf{1}}$, NIRUPAMA PRAKASH ${ }^{2} \&$ H VIKRAM ARORA $^{\mathbf{3}}$ \\ ${ }^{1}$ PhD Scholar, Amity Institute of Social Sciences, Amity University, Noida, Uttar-Pradesh, India \\ ${ }^{2}$ Head of the Institute, Amity Institute of Social Sciences, Amity University, Noida, Uttar-Pradesh, India \\ ${ }^{3}$ Director, Bestlife Consulting Services, Noida Uttar-Pradesh, India
}

\begin{abstract}
Use of project management software in organizations has increased in recent years. There is a rising trend of working from remote locations which has led to an increased demand for data that is accessible at any time, from anywhere. Pandemic outbreaks like COVID-19 make it difficult to work with groups and communities like in normal circumstances. Virtually communicating is the only way in such circumstances and that is where technology is used at its best. There are thousands of Non-Governmental Organizations (NGOs) which are working actively in almost every part of India. They are trying their best to fulfil society's needs and it depends on project-based funding. Although the livelihoods of many people depend on NGOs' ability as to how effectively they deliver project, depends on many factors, project management (PM) being one of them. This study tries to find out about the use of Project Management Software by $N G O$ 's and if it has impact on Employee Efficiency.

KEYWORDS: Project Management, Software, Technology
\end{abstract}

Received: May 13, 2020; Accepted: Jun 03, 2020; Published: Aug 05, 2020; Paper Id.: IJMPERDJUN2020627

\section{INTRODUCTION}

The use of project management software in organizations has increased in recent years. This period has seen developments in the field of digital computing, combined with the use of telecommunications technology, in order to link many computers into what is 'virtually' a very large single network, the Internet. In this modern age, organizations are constantly looking for new methods to create a workforce which can be more productive, efficient and innovative. There is a rising trend of working from remote locations which has led to an increased demand for data that is accessible at any time, from anywhere. With the advances in computing, data management and automation work has become easier. ICT extends its benefits not only to its contribution in the industry, but it has also spread into the everyday life. Furthermore, current technologies allow communication to be conducted effectively, which is important when decision-making and response time in emergency situation plays a critical role. The effectiveness and speed in such situations are not the only factors that are important, but it is also important how this information is transferred and communicated. Organizational communication which includes both internal processes of communication (among the members of the organization itself) and communication towards the outside (how the organization presents itself and exchanges information with external stakeholders). In fact, modern-day workers demand connectivity and technology. Pandemic outbreaks like COVID-19 make it difficult to work with groups and communities like in normal circumstances. Virtually communicating is the only way in such circumstances and that is where technology is used at its best.

There are thousands of Non-Governmental Organizations (NGOs) which are working actively in almost 
every part of India. They are trying their best to fulfil society's needs and it depends on project-based funding. Although the livelihoods of many people depend on NGOs' ability as to how effectively they deliver project, depends on many factors, project management (PM) being one of them. There are many methodologies created and adapted exclusively for NGOs, there is still no significant evidence on wide application in this sector. The Non-governmental organizations form a heterogeneous group as some are CBOs (community-based organizations), social movement organizations, private voluntary organizations, civil society, self-help organizations, grassroots organizations etc. They also vary in size, scope, targets, structures and motivation. As a result of which, they face a lot of challenges which clubs together with non-availability of proper project management methodology which usually leads to poor project planning, scarcity of accountability and stakeholder involvement, complexity of inter-related tasks, superficial risk management strategies, unmotivated project team and eventually-bad quality, losses of time and money.

This is where the role of web-based technology comes into place. In this modern age, organizations are constantly looking for new methods to create a workforce which can be more productive, efficient and innovative. There is a rising trend of working from remote locations which has led to an increased demand for data that is accessible at any time, from anywhere. With the advances in computing, data management and automation work has become easier. ICT extends its benefits not only to its contribution in the industry, but it has also spread into the everyday life. Furthermore, current technologies allow communication to be conducted effectively, which is important when decision-making and response time in emergency situations plays a critical role. The effectiveness and speed in such situations are not the only factors that are important, but it is also important how this information is transferred and communicated.

We are living in the age of technology, right from waking up till we go to bed. When we speak of Organizations, technology is helping them to reach out to more people. According to a report published in Global NGO Online Technology Report (techreport.ngo) in 2017, it spoke of how non-government organizations worldwide use web applications and email communications, online and mobile fundraising tools and social and mobile media. According to the report it stated that there will be an improvement in infrastructure all over the world by 2025 as a result of which NGOs will become more empowered and can create significant social change. It was also found that $71 \%$ of NGOs regularly send email updates to donors and supporters, while $92 \%$ of global NGOs have a Facebook page and $72 \%$ a Twitter handle.

There are different ways as to how different Organizations use technology to ease out work. There is a rising trend of working from remote locations which has led to an increased demand for data that is accessible at any time, from anywhere. With the advances in computing, data management and automation work has become easier. ICT extends its benefits not only to its contribution in the industry, but it has also spread into the everyday life. Furthermore, current technologies allow communication to be conducted effectively, which is important when decision-making and response time in emergency situations play a critical role. The effectiveness and speed in such situations are not the only factors that are important, but it is also important how this information is transferred and communicated.

\subsection{Ways to Increase User Base Through the Use of Technology:}

Be it through social media or other ways to connect to the outer world, technology has contributed a lot towards the nongovernments in increasing their networks. Networking is a Two-Way Street which involves interacting with others. Software technologies which includes software like content management, portals, document management, knowledge management, customer relationship management, online survey forms, donation forms, connect form etc. and the commonality among all of this technology is content. These technologies try to organize customers, documents, or Web pages - represent an attempt 
to harness and organize content and make it available to the target groups. Combining technology with changing stakeholder expectations from the non- governments, is forcing them to become more transparent and responsive. A single organization runs multiple projects, which now with the help of these software can be managed easily are it accounting, credibility or any other.

\subsection{Ways to Enhance Communication Within the Organization:}

1.2.1. Instant Messaging: Instant messaging services are a quicker way of delivering messages. It can be incorporated in different web based software which are used by the organization. The person in charge can easily assign work to employees through this way. This can also work vice versa as for the employees within the organization can also report or send a query to their superiors via text messaging. With the help of this technology communication can be simplified and instantly accessible.

1.2.2. Email: This is the most used means of communication across the globe by all organizations. Their so many communication technologies which have tried to replace electronic mail, but none of them have succeeded. This is also a formal way to communicate and network. It is considered as one of the key parts of an 'e-revolution' in workplace communication. Sending an email is much less expensive and reduce cost as instead of sending letters through post, this saves time as well as money.

1.2.3. Online Transaction Processing (OLTP): OLTP (online transaction processing) is a type of software programs which are used for supporting transaction-oriented applications over the internet. these systems are mostly used for works like case entries, financial transaction tracking, user relationship management. These systems are often decentralized. It has the ability to maintain concurrency, availability, speed and recoverability. There is immediate system response to user requests.

1.2.4. Online Analytical Processing (OLAP): Online Analytical Processing (OLAP) is computer processing that enables a user to easily and selectively extract and view data from different points of view. For example, a user can request that data be analysed to display a spreadsheet showing all of an organisations cases or activities running in the month of July, compare figures with those for the same activities in September, and then see a comparison of them in the same time period. OLAP enables users to analyse multidimensional data interactively from multiple perspectives. OLAP consists of three basic analytical operations: consolidation (roll-up), drill-down, and slicing and dicing.

1.2.5. Decentralized Computing: Decentralized computing is the allocation of resources, both hardware and software, to each individual workstation, or office location. This means employees in an organization will access shared information. This process of communication within an organization is less expensive and more effective because all computers will be accessing a centralized database to get all the information. For some organizations they set up websites through which workers can login and access essential data and communicate with other employees in the same online platform.

1.3. Usage of Technology which has changed how NGOs Function. Some of the Areas which has been Impacted with 


\section{its Use are:}

\subsubsection{Increased Efficiency}

NGO can maximize the donation fund by reducing the internal processing time of its expense management system. This allows agency to focus on front-end process.

\subsubsection{Improved Assistance Delivery}

NGOs dedicatedly work on helping kids and adults in their well-being and to fulfill the basic necessity through donation. To improve the assistance delivery, they work on automated and inventory system. Moreover, it has helped in increasing the efforts while maintaining minimum volunteers.

\subsubsection{Better Resource Management}

With the use of right technology, NGO can ensure of better resource management. Optimum resource will help in using resources efficient way and also helps reducing the cost. Organization has better insight of deploying manpower to specific project that would reach out to maximum.

\subsubsection{Better Project Management}

Using technology, NGOs can better manage their projects and also work virtually at times and connect to their partners as well as the beneficiaries within a short span of time.

With the help of technology organisations are able to reach out to people with positive transformation which has brought into a crucial play a role in sustainable development.

\section{OBJECTIVES OF THE STUDY}

\section{The Objectives of the Present Study Are}

- $\quad$ To understand the type of technology used by NGO's

- $\quad$ To understand the impact of using project management software in employees work efficiency

\section{METHODOLOGY}

The present research study is an attempt to examine the type of technology used by NGO's in their organizations and also to understand the impact of using project management software in employees work efficiency. Quantitative approach has been adopted The researcher collected data using self-made semi structured interview schedule. The data collected from the field was analysed using the software called Statistical Package for Social Science (SPSS).

\section{FINDINGS}

Data was collected by interviewing 40 respondents about their experiences of working at distinct grass root NGO's and how they use technology at their workplace. 32 questions are asked in the survey to understand their use cases of technology at workplace. The collected data is further tabulated and analysed to understand the impact of project management software by NGO's and impact on the efficiency of the employees. The following tables and graps the data which was collected with the help of a questionnaire to find out the different aspects of web-based program management software's as well as to understand the type of technology used by organisations. 


\subsection{What is Your Designation?}

There was a mixed group of employees at various designations. We divided them into 4 levels based on their role. Same questionnaire was presented to all the participants and responses were collected to understand the use of project management software by NGO's and its impact on employee efficiency.

\begin{tabular}{l|r|r|} 
& \multicolumn{2}{|c|}{ D } \\
\hline Animator & Frequency & Percent \\
\cline { 1 - 3 } \cline { 2 - 3 } & 9 & 22.5 \\
\hline Supervisor & 9 & 22.5 \\
\hline Manager & 15 & 37.5 \\
\hline Director & 7 & 17.5 \\
\hline Total & 40 & 100.0 \\
\hline
\end{tabular}

Figure 1

\subsection{What is Your Educational Qualification?}

It was found that the majority of the employees working in the organisation were graduates. The minimum qualification which the employees obtained was clearing class $10^{\text {th }} .55 \%$ of the respondents were graduates followed by $22.5 \%$ obtaining their higher secondary degree.

This question is relevant to the study as if the employees are qualified, they will be open minded for changes which might ease up the work. It also signifies competency towards working effectively.

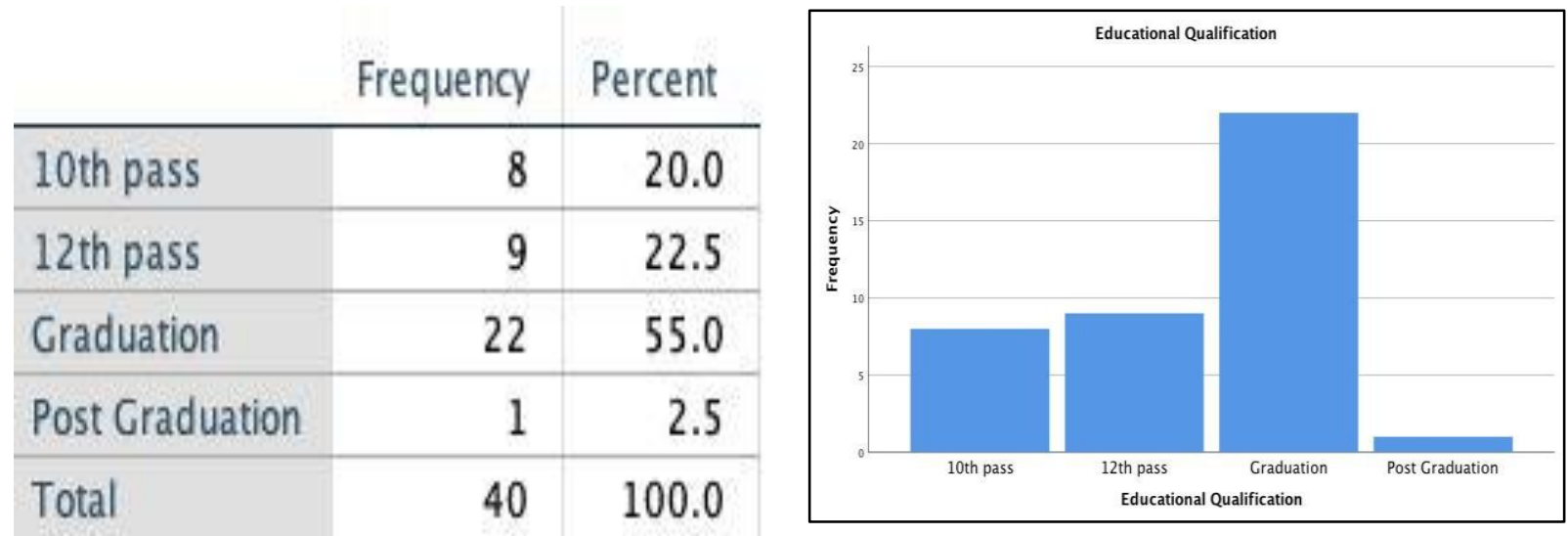

Figure 2

\subsection{How many projects are you handling at your workplace?}

From the data collected from the organisations, it was found that majority of the organisations had 2 projects. $75 \%$ of the respondents stated that they were handling 2 projects in their organisation.

Organisation handling more project means they need some kind of technological support which would help in efficient handling of multiple projects. This question is important as it helps the researcher in formulating intervention techniques for the organisation for her research. 


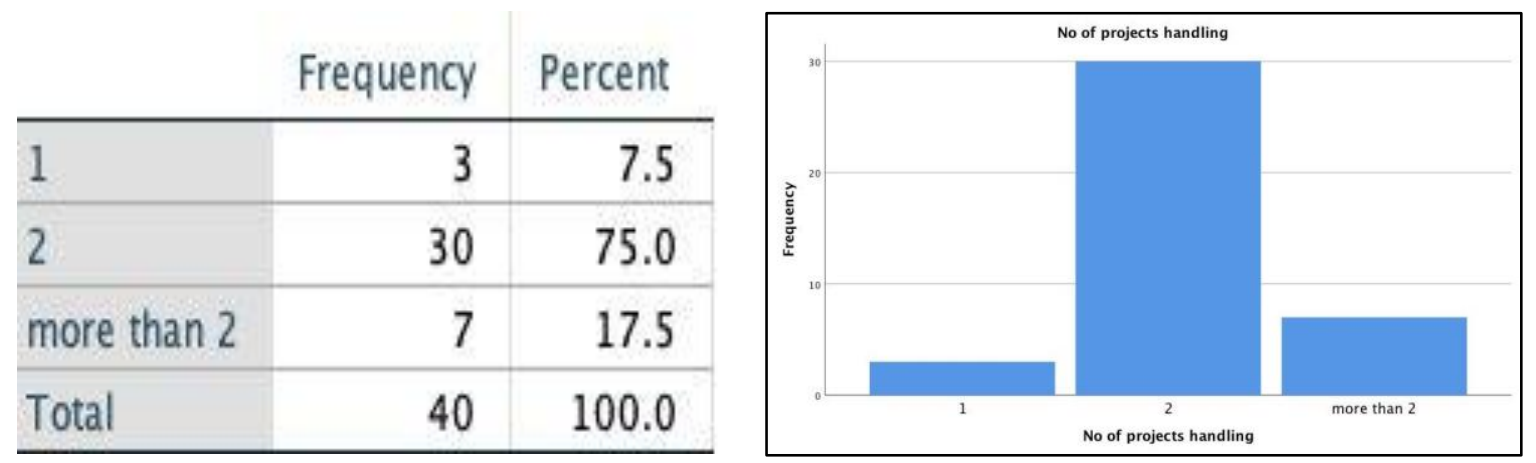

Figure 3

\subsection{What is Your Gender?}

The data was collected from the organisations consisting of 40 respondents. Out of the 40 respondents, $57.5 \%$ were males which counts to 23 out of the 40 respondents. This question is to find out if there is any relationship between gender and use of technology.

\begin{tabular}{|l|r|r|} 
& Frequency & Percent \\
\hline Male & 23 & 57.5 \\
\hline Female & 17 & 42.5 \\
\hline Total & 40 & 100.0 \\
\hline
\end{tabular}

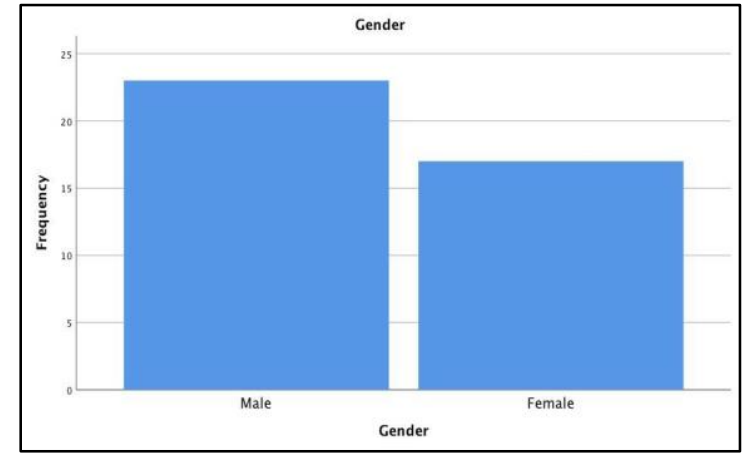

Figure 4

\subsection{How Many Staff Members are There in Your Organisation?}

The data was collected from different NGOs. There were 40 respondents from this organisation. It was found that majority of the organisation i.e. $45 \%$ stated that they have 4 staff members followed by $35 \%$ of the respondents stating they have more than 4 staff members. This would help the researcher to know if there are more people working in a single organisation, which would help to find if more collaboration will lead to use of web based software.

\begin{tabular}{l|r|r|} 
& Frequency & Percent \\
\hline 2 & 1 & 2.5 \\
\hline upto 3 & 7 & 17.5 \\
\hline upto 4 & 18 & 45.0 \\
\hline more than 4 & 14 & 35.0 \\
\hline Total & 40 & 100.0 \\
\hline
\end{tabular}

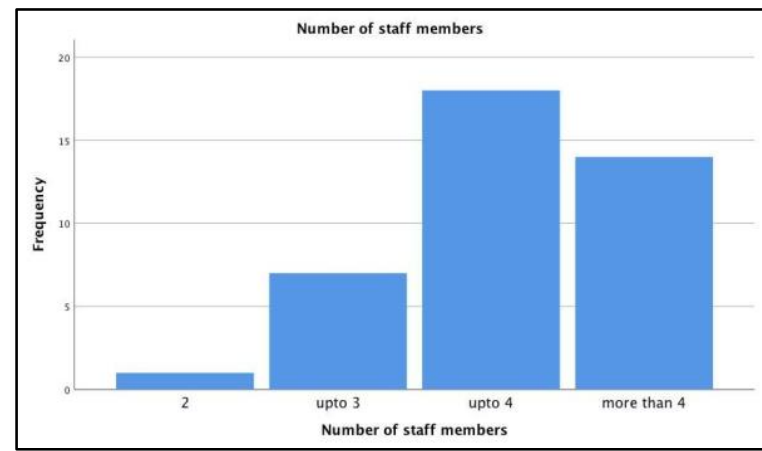

Figure 5

\subsection{Does Your Organisation Have A Website?}


Out of the 40 respondents, majority of them i.e. 26 out of 40 respondents stated that their organisation don't have a website. Most of the grassroot organisation does not have an online presence to support their good work. This questions is significant as this would help to understand the status of the presence in the internet and would further help in intervention.

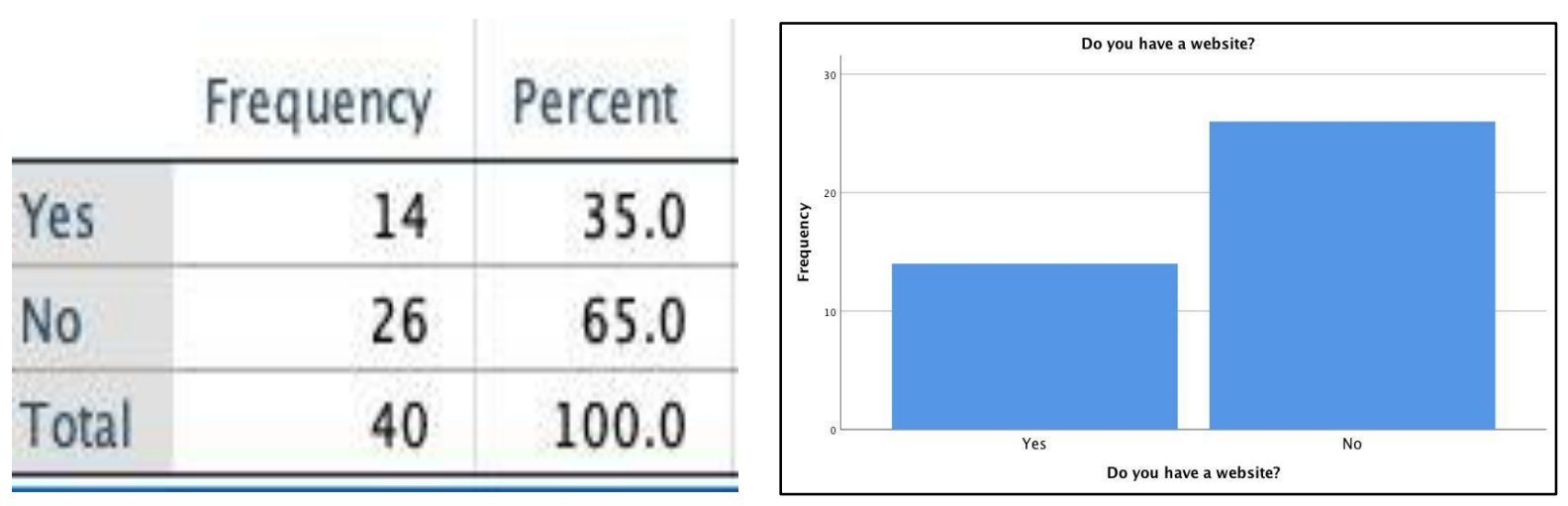

Figure 6

\subsection{How Do You Communicate Work Related Information among Your Staff Members?}

Communication is an important element for proper function of an organisation. From the data collected it was found that majority of the communication happens via phone calls which is $35 \%$ followed by people using software is to communicate with the team members which is $32.5 \%$. This question is significant as this would help in understanding the ways how the intra communication takes place within the organisation as we as the stakeholders and sponsors.

\begin{tabular}{l|r|r|} 
& Frequency & Percent \\
\hline SMS & 2 & 5.0 \\
\hline Whats App & 11 & 27.5 \\
\hline Software & 13 & 32.5 \\
\hline Phone call & 14 & 35.0 \\
\hline Total & 40 & 100.0
\end{tabular}

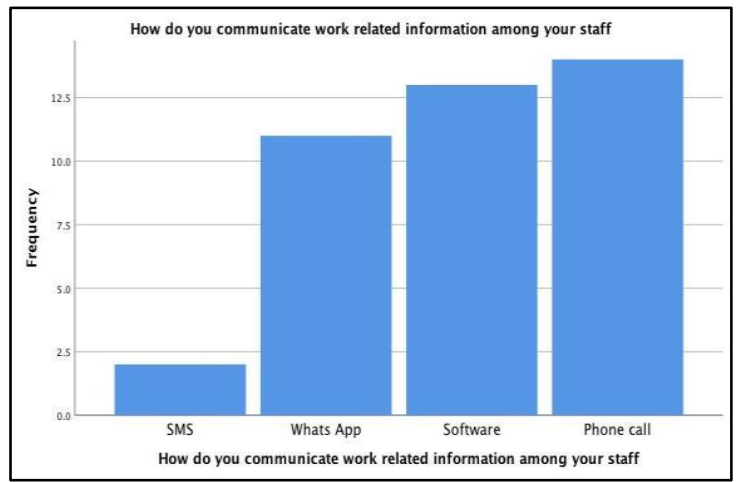

Figure 7

\subsection{Do You Feel The Need of Technology for Efficient Functioning / Reporting at Your Workplace?}

Reporting is an important element for NGOs whether it is for self or for the funding agency. From the data collected it was found that majority of the respondents felt that there is a need of technology for efficient functioning or reporting at the workplace. $65 \%$ of the respondents agreed to this. Statistics on this question would help to have an understanding on the perceptions of using technology in the workplace. 


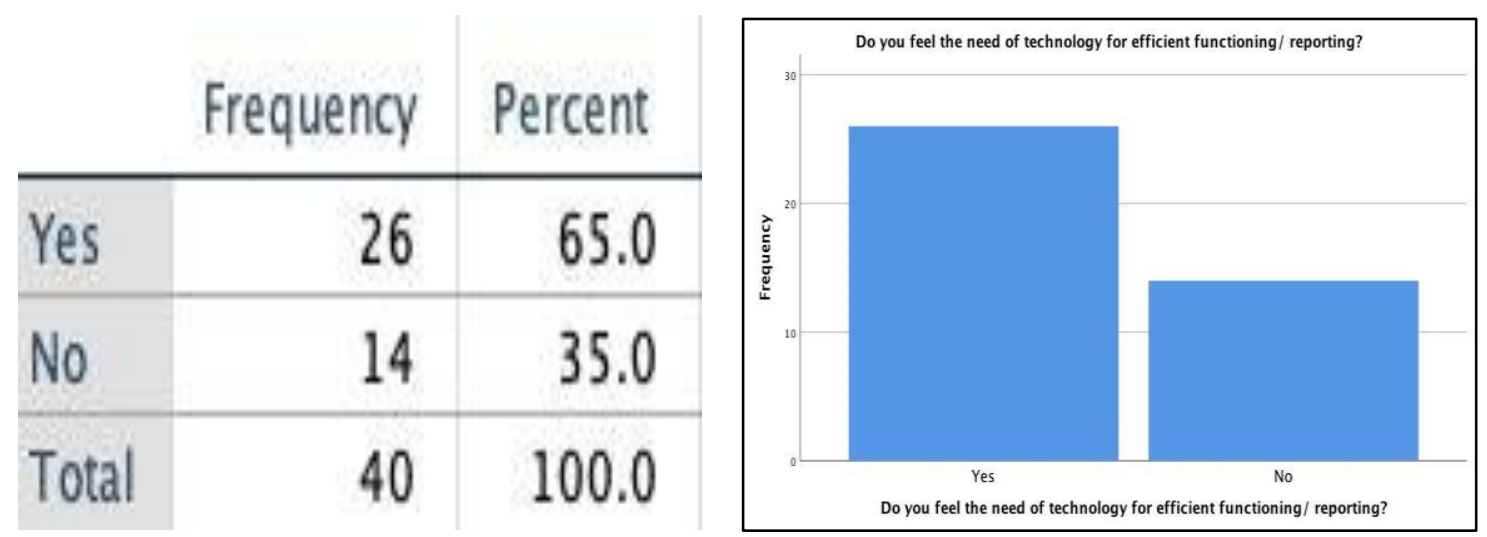

Figure 8

\subsection{Do You Think with The Introduction of Technology, You Will Be Able To Reach More Target Population?}

From the data collected from the respondent's majority of them responded that they feel that with the introduction of technology they will be able to reach more to the target population with 67.5 people agreeing to this. This is significant to the study as it would help in understanding the perceptions of the employees working in the NGO's if they feel they you reach out to larger target population with the intervention of technology.

\begin{tabular}{l|r|r} 
& Frequency & Percent \\
\hline Yes & 27 & 67.5 \\
\hline No & 13 & 32.5 \\
\hline Total & 40 & 100.0 \\
\hline
\end{tabular}

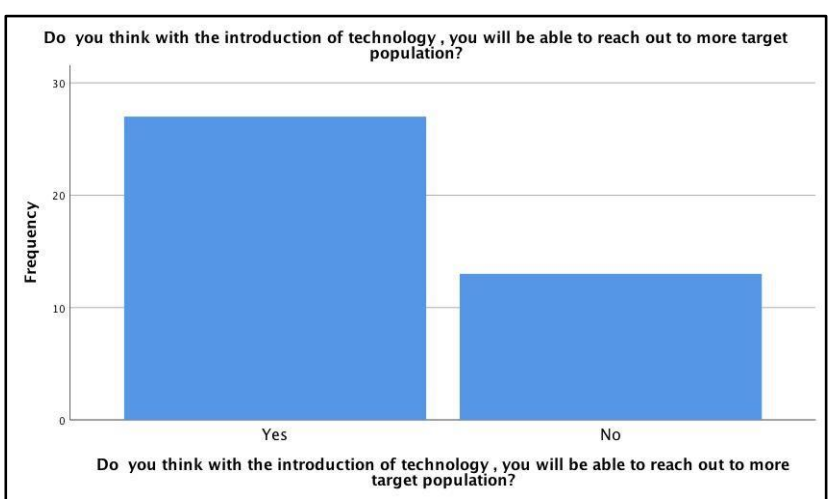

Figure 9

\subsection{Is Security One of the Main Reasons for Not Using ICT?}

Using ICT has its own disadvantage as well as advantages. Majority of the respondents that is 67.5 people did not believe that security as one of the main reasons for not using ICT. This question is significant as finding out if security is the reason of not using technology would help in better intervention strategies which would keep in mind of the security concern.

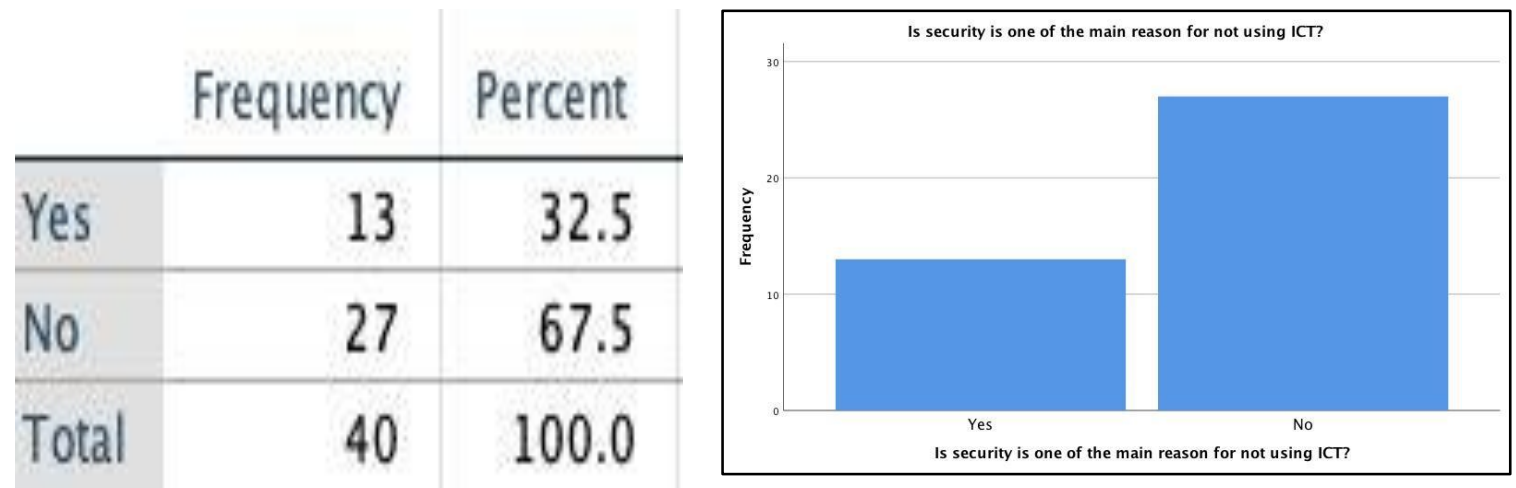

Figure 10 


\subsection{Have You Heard of Project Management Systems?}

Majority of the respondents who are mostly from grassroot organisations stated that they have not heard of project management systems with $52.5 \%$ stating that they have not been introduced to project management systems. This is a significant question to the research as if the employees are not aware of project management systems, the researcher would plan to create awareness before intervening project management systems.

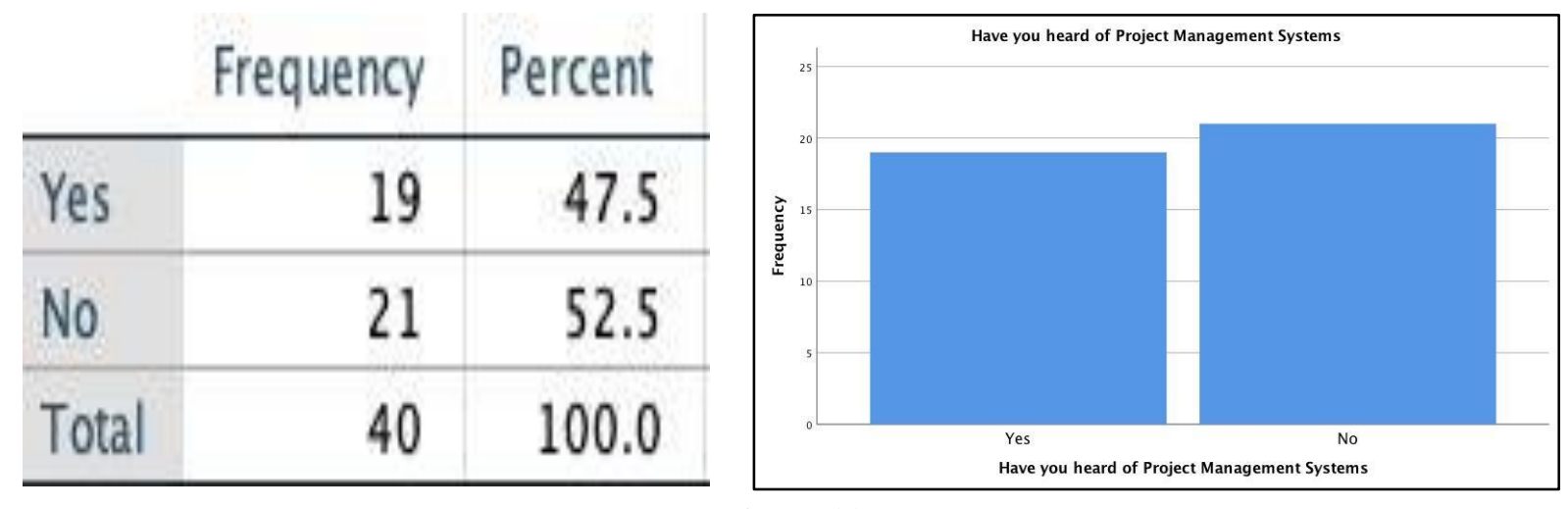

Figure 11

\subsection{Do You Think That Technology Helps In Meeting Commitments On Time?}

Says it was found that 27 out of 40 respondents believe that technology helps in meeting commitments on time. Technology is timesaving which leads to improving work performance. This can be a very significant question for the research as this could be the parameter to measure the effectiveness of intervention of technology to improve employee efficiency

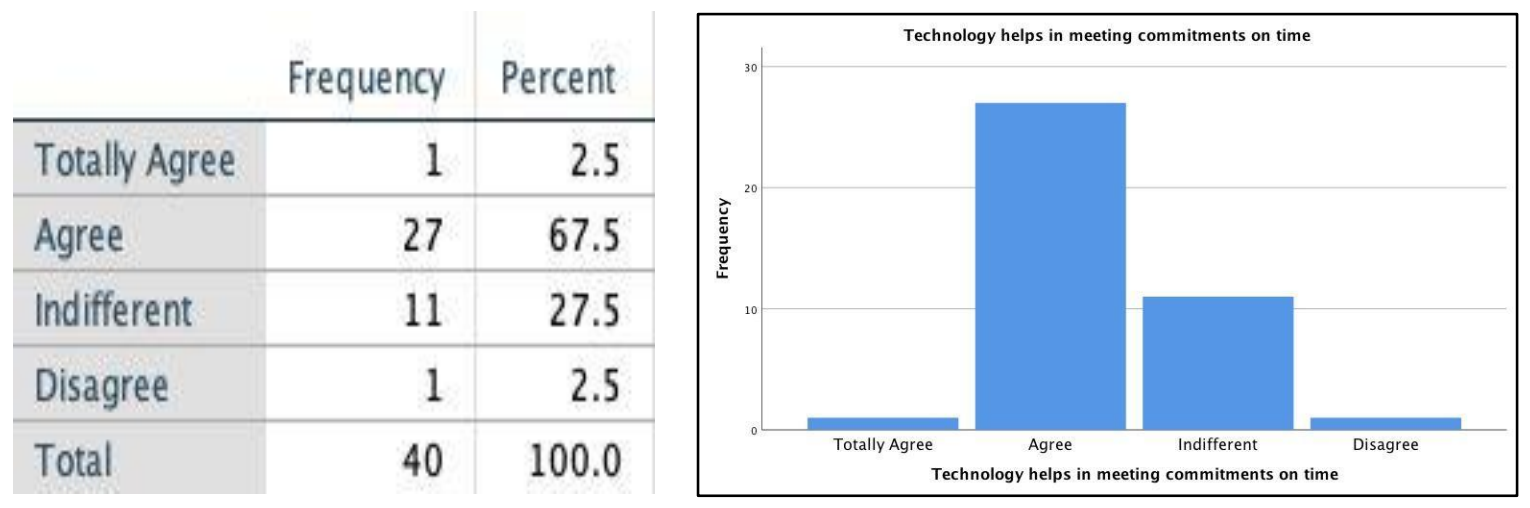

Figure 12

\subsection{Do You Feel That It Takes Less Time To Complete Complex Work When Using Project Management System?}

From the analysis done it was found that most of the respondents that is 30 out of the 40 respondents shared that they believe it would take less time to complete their projects as well as works or reports if they are using a project management system. This can be a very significant question for the research as this could be the parameter to measure the effectiveness of intervention of technology to improve employee efficiency. This would help in building the intervention strategy. 


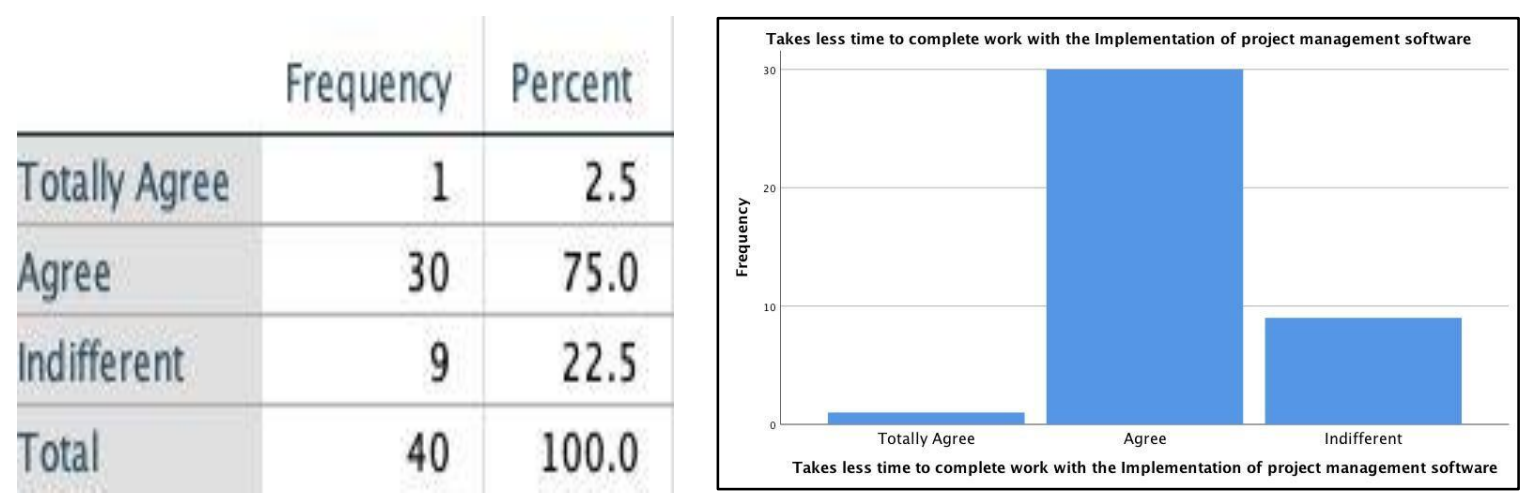

Figure 13

\subsection{Do You Feel Energetic at Workplace?}

From the data collected, it was found that majority of the respondents that is $50 \%$ agreed that they feel energetic at work. This leads to better work efficiency in the workplace.

\begin{tabular}{|l|r|r|} 
& Frequency & Percent \\
\hline Totally Agree & 3 & 7.5 \\
\hline Agree & 20 & 50.0 \\
\hline Indifferent & 13 & 32.5 \\
\hline Disagree & 4 & 10.0 \\
\hline Total & 40 & 100.0
\end{tabular}

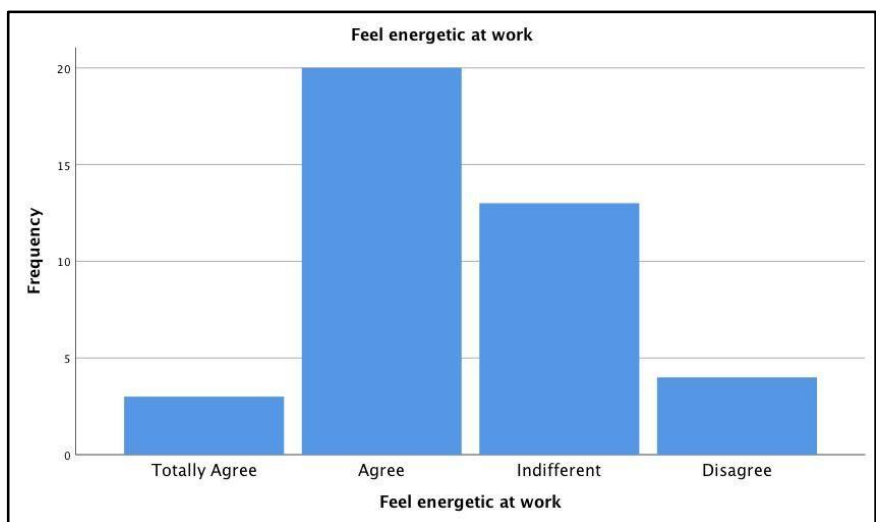

Figure 13

\subsection{Is Your Job Inspiring?}

Majority of the respondents stated that they agreed that the job is inspiring. Most of the non-government organisations work with a noble cause and with the vulnerable sections of the society. $57.5 \%$ agreed that their job is inspiring. This question is relevant as if the employees are willing to innovate and go an extra mile to do the job. They would do so if the job is inspiring to them, so they would be willing to embrace change through use of project management software.

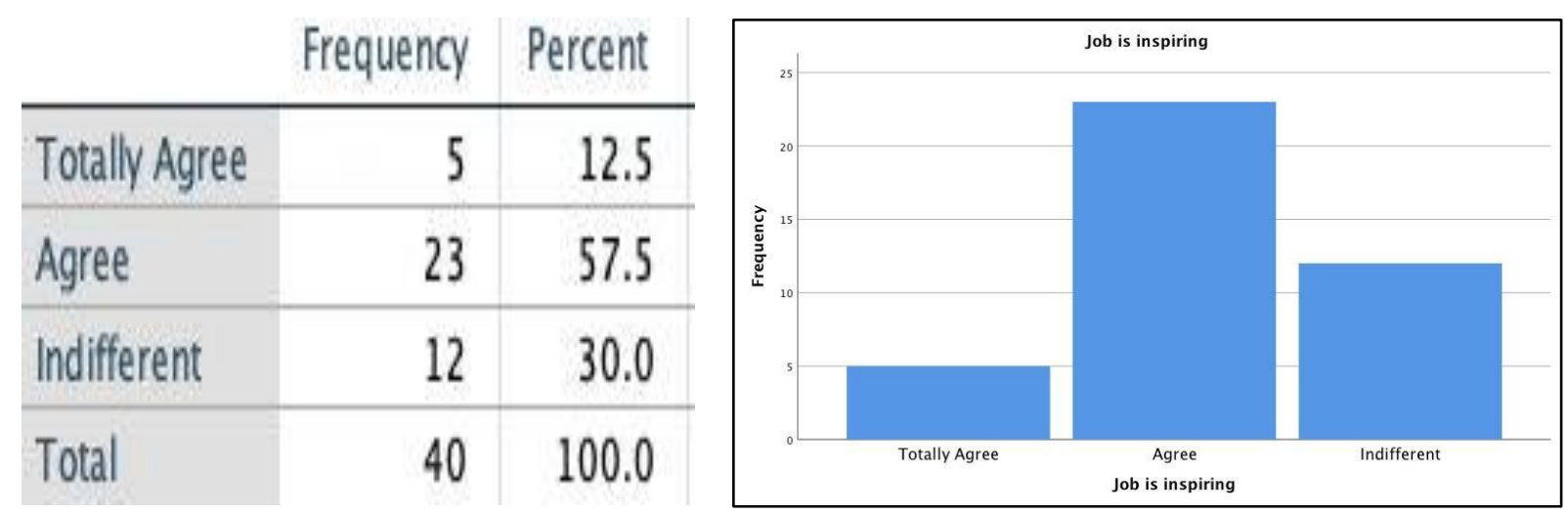

Figure 14 


\subsection{Do You Get a Sense of Fulfilment After Completing the Work in Your Office?}

From the analysis it was found that 27 out of the 40 respondents agreed that they have a sense of fulfilment after completing their work in office. 7 out of 20 respondents totally agreed to the statement. This question is relevant as if the employees are willing to innovate and go an extra mile to do the job. They would do so if the job is inspiring to them, so they would be willing to embrace change through use of project management software.

\begin{tabular}{l|r|r|} 
& Frequency & Percent \\
\hline Totally Agree & 7 & 17.5 \\
\hline Agree & 27 & 67.5 \\
\hline Indifferent & 5 & 12.5 \\
\hline Disagree & 1 & 2.5 \\
\hline Total & 40 & 100.0 \\
\hline
\end{tabular}

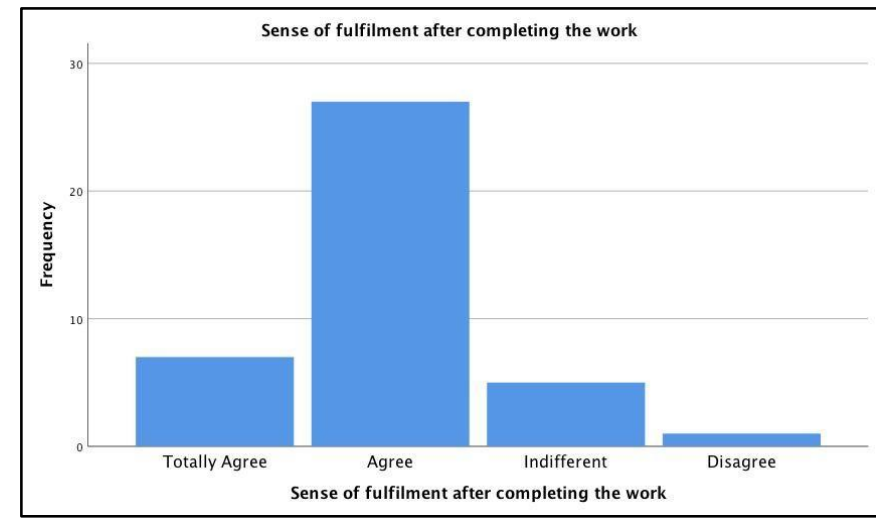

Figure 15

\subsection{Are You Willing to Accept All Sorts of Challenge at Work?}

From the data collected from 40 respondents, 27 of them agreed that they are willing to accept all sorts of challenge in the work.

\begin{tabular}{|l|r|r|} 
& Frequency & Percent \\
\hline Totally Agree & 6 & 15.0 \\
\hline Agree & 27 & 67.5 \\
\hline Indifferent & 6 & 15.0 \\
\hline Disagree & 1 & 2.5 \\
\hline Total & 40 & 100.0 \\
\hline
\end{tabular}

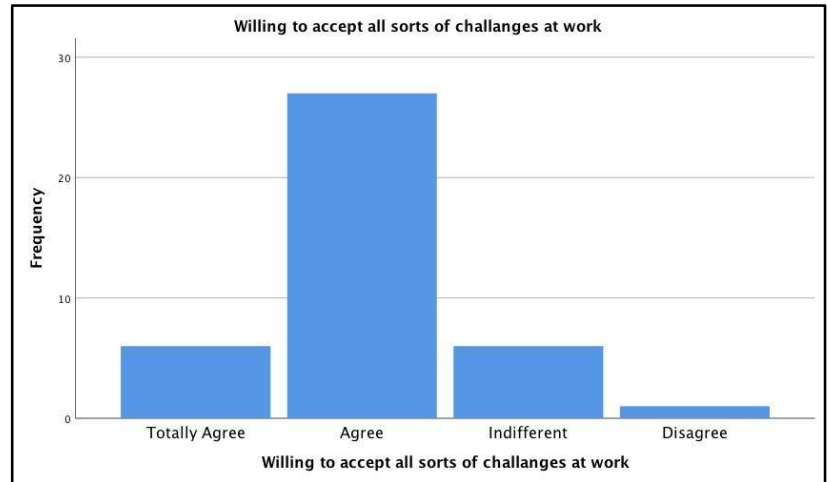

Figure 16

\subsection{Do You Feel That Everyone in the Team Cooperates to Get the Work Done?}

From the data collected it was found that 26 out of 40 respondents felt that everyone in the team cooperates to get the work done. Teamwork is essential and majority of them agrees to the fact that they get support from the team members. 


\begin{tabular}{l|r|r} 
& Frequency & Percent \\
\hline Totally Agree & 5 & 12.5 \\
\hline Agree & 26 & 65.0 \\
\hline Indifferent & 8 & 20.0 \\
\hline Disagree & 1 & 2.5 \\
\hline Total & 40 & 100.0 \\
\hline
\end{tabular}

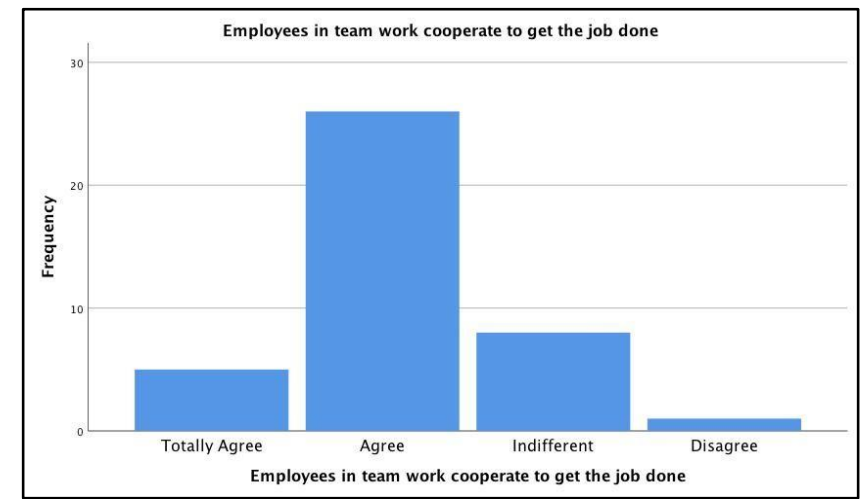

Figure 17

\subsection{Do You Have the Freedom to Decide How to Do the Job?}

From the analysis done on the data collected it was found that $50 \%$ of the respondents agree that they have freedom to decide how to do the job allotted to them. 10 of the 40 respondents disagree that they don't have the freedom to decide on how to do the job. This response is mostly from the animators who work at the ground level

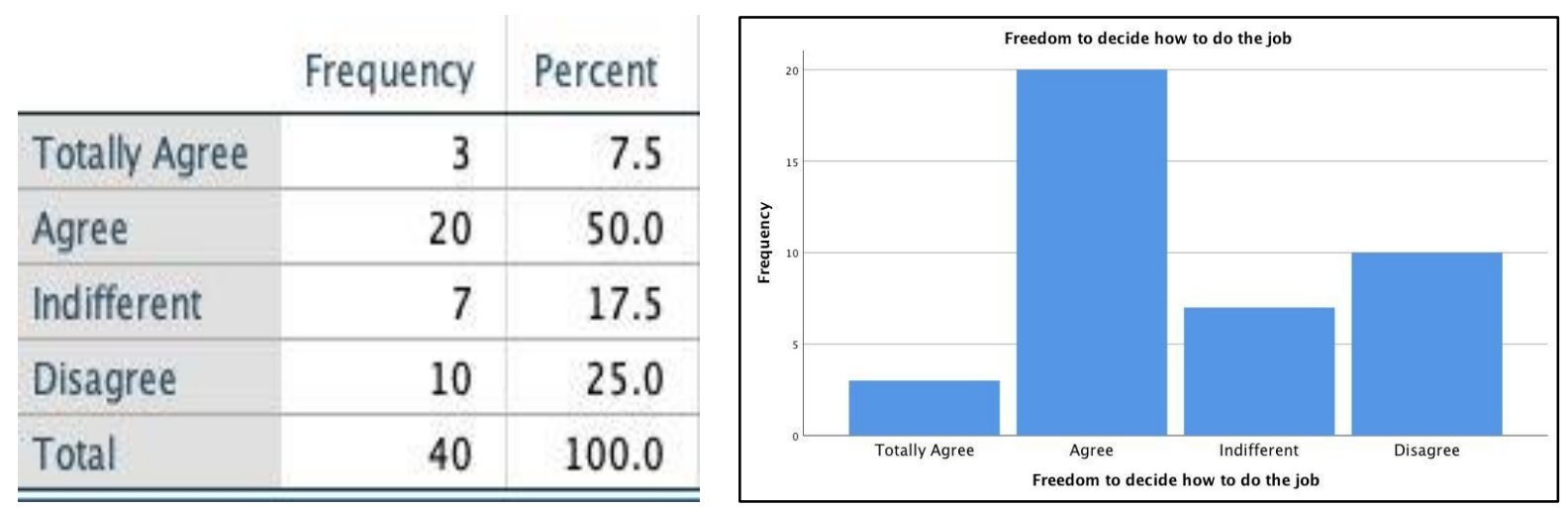

Figure 18

\subsection{Do You Feel Like a Part of the Big Family in the Organisation?}

From the data collected from 40 respondents, 24 of them stated that they feel like a part of the organisation. Person that is eight 0 out of 40 respondents stated that there in different that is neither do they feel like a part of a family nor they have a feeling that they don't belong a part of the organisation. Having a feeling of belongingness will have in better intervention of the project management software as they would try to do better for the organisation.

\begin{tabular}{l|r|r} 
& Frequency & Percent \\
\hline Totally Agree & 3 & 7.5 \\
\hline Agree & 24 & 60.0 \\
\hline Indifferent & 8 & 20.0 \\
\hline Disagree & 3 & 7.5 \\
\hline Totally Disagree & 2 & 5.0 \\
\hline Total & 40 & 100.0 \\
\hline \hline
\end{tabular}

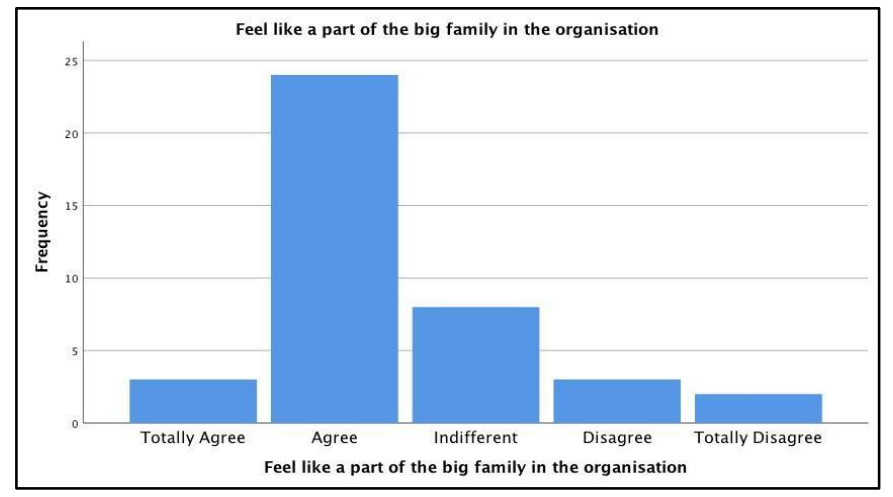

Figure 19 


\subsection{Flexibility in Schedules}

Data collected it was analysed that majority of the respondents agreed to the fact that they are given flexibility in work schedules. 22 out of 40 respondents agreed to this followed by 13 who neither agreed not disagree to this.

Table 1 show we considered 4 factors to measure the impact of technology on the engagement level and efficiency of the employees. The efficiency was also linked with the designation of an employee. In this One Way ANOVA, we studied the equality of means of their performance efficiency and their designation. The significant $p$-value of all the factors is quite high, exceeding $40 \%$ in 1 case and $15 \%$ in the other. However, low p-value for willingness to accept the challenges at workplace across all the designations indicates that people desire to be efficient. Further intervention is required to understand the impact of other factors on the employee engagement and efficiency.

Table 2 shows we conducted an independent samples t-test to understand the relationship between the employee engagement and gender. The scale for these questionnaire measured on 1-5 indicates that low scores as positive responses. The $t$ test for null difference among the means has 0 in the confidence interval, indicating that it is highly probable that the difference of the means is zero. This suggests that our hypothesis of equal means among the factors has strong evidence and the study indicates that there is a strong correlation between our sample with the population.

Further analysis of these factors is required to understand the coherence between factors and intervention research is suggested with large dataset and more questions to understand the impact of technology on employee engagement and efficiency.

Table 4: Independent samples t Test to understand the relationship between use of project management systems and employee engagement / efficiency

Table 4 shows we conducted an independent samples t-test to understand the relationship between the employee productivity and use of project management systems. The scale for these questionnaire measured on 1-5 indicates that low scores as positive responses. The $t$ test for null difference among the means has 0 in the confidence interval, indicating that it is highly probable that the difference of the means is zero. This suggests that our hypothesis of equal means among the factors has strong evidence and the study indicates that there is a strong correlation between our samples with the population.

Further analysis of these factors is required to understand the coherence between factors and intervention research is suggested with large dataset and more questions to understand the impact of technology on employee productivity when project management systems are used.

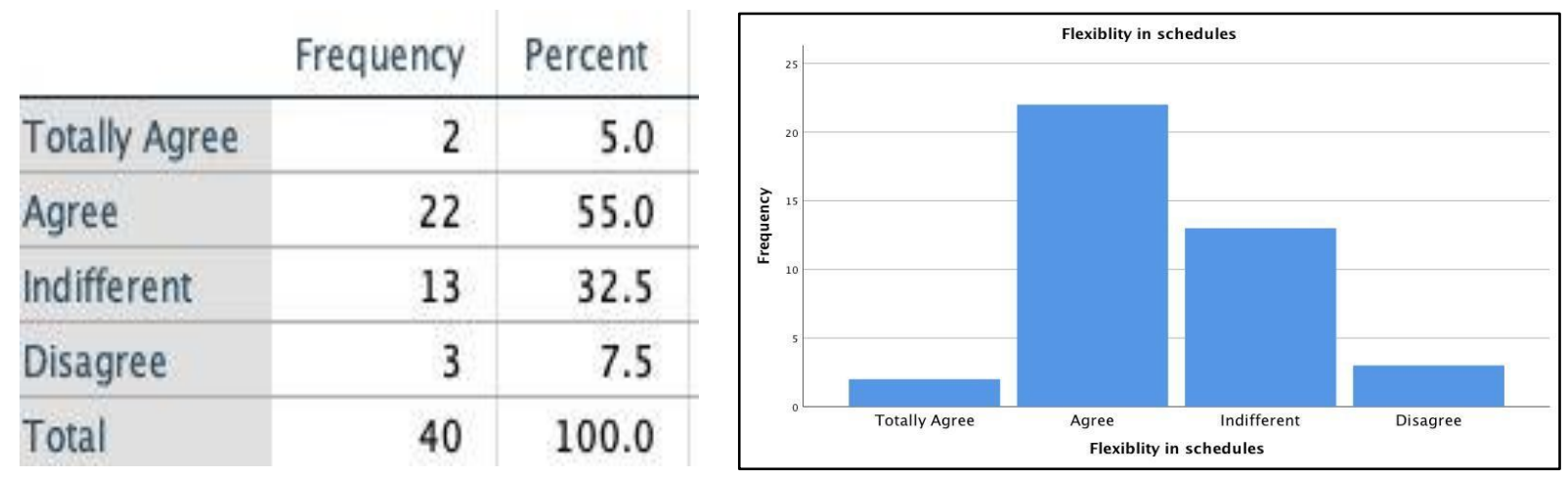

Figure 20 
Table 1: One Way ANOVA-to Understand the Relation Between Means of Employee Efficiency and Designation

\begin{tabular}{|c|c|c|c|c|c|c|}
\hline & & $\begin{array}{l}\text { Sum of } \\
\text { Squares }\end{array}$ & $\mathrm{df}$ & Mean Square & $\mathrm{F}$ & Sig. \\
\hline \multirow[t]{3}{*}{ Feel energetic at work } & Between Groups & 1.754 & 3 & .585 & .950 & .427 \\
\hline & Within Groups & 22.146 & 36 & .615 & & \\
\hline & Total & 23.900 & 39 & & & \\
\hline \multirow[t]{3}{*}{ Job is inspiring } & Between Groups & 2.124 & 3 & .708 & 1.867 & .153 \\
\hline & Within Groups & 13.651 & 36 & .379 & & \\
\hline & Total & 15.775 & 39 & & & \\
\hline \multirow{3}{*}{$\begin{array}{l}\text { Sense of fulfilment after } \\
\text { completing the work }\end{array}$} & Between Groups & 4.527 & 3 & 1.509 & 4.735 & .007 \\
\hline & Within Groups & 11.473 & 36 & .319 & & \\
\hline & Total & 16.000 & 39 & & & \\
\hline \multirow{3}{*}{$\begin{array}{l}\text { Willing to accept all } \\
\text { sorts of challanges at } \\
\text { work }\end{array}$} & Between Groups & 3.983 & 3 & 1.328 & 4.010 & .015 \\
\hline & Within Groups & 11.917 & 36 & .331 & & \\
\hline & Total & 15.900 & 39 & & & \\
\hline
\end{tabular}

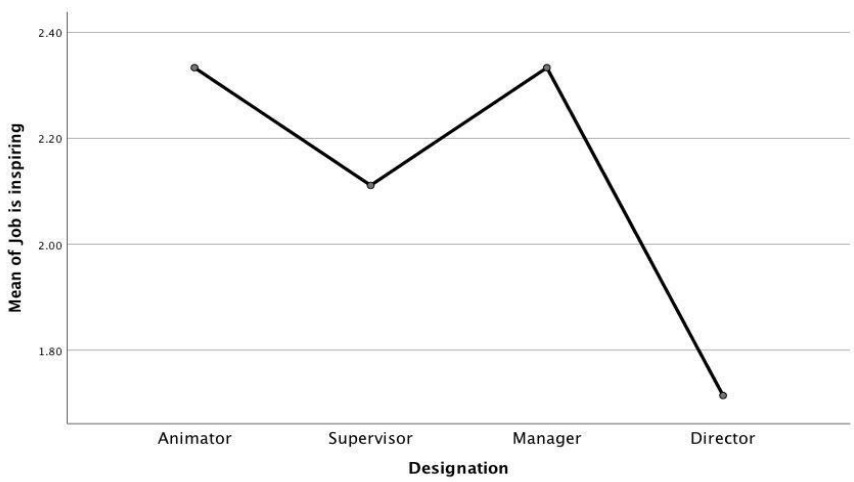

Figure 21

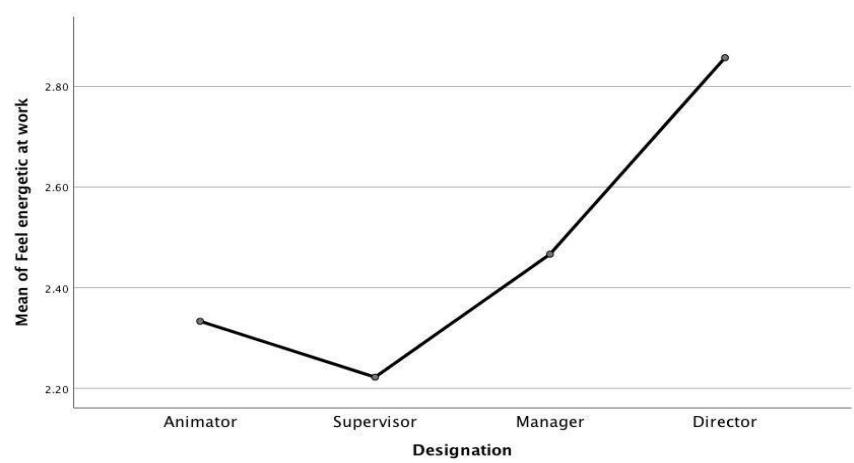

Figure 22

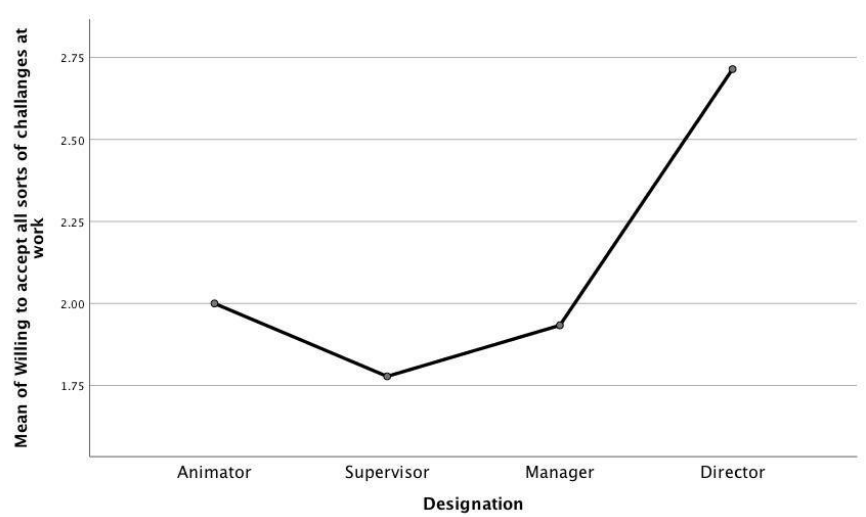

Figure 23 


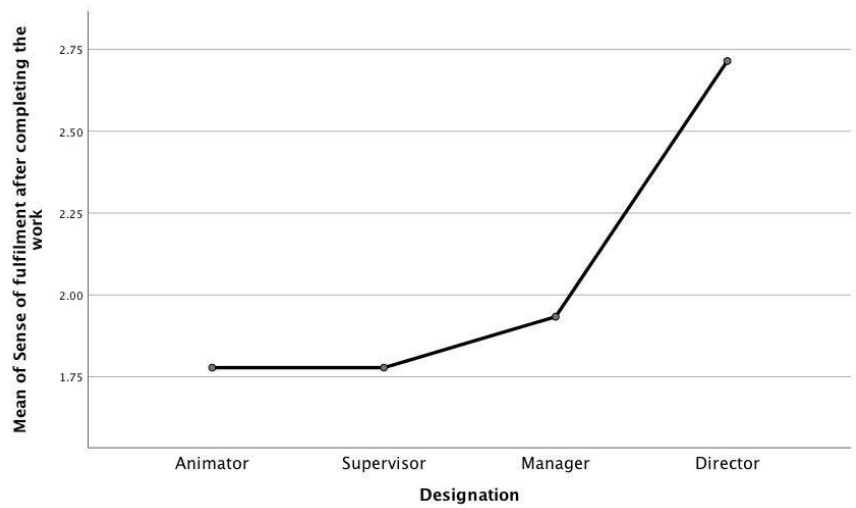

Figure 24

Table 2: Independent Samples t Test to Understand the Relationship between Gender and Employee Engagement and Efficiency

\begin{tabular}{lll|l|r|r} 
& Gender & $\mathrm{N}$ & Mean & \multicolumn{1}{c}{$\begin{array}{c}\text { Std. } \\
\text { Deviation }\end{array}$} & $\begin{array}{c}\text { Std. Error } \\
\text { Mean }\end{array}$ \\
\hline Feel energetic at work & Male & 23 & 2.6087 & .83878 & .17490 \\
\cline { 2 - 7 } & Female & 17 & 2.2353 & .66421 & .16109 \\
\hline Job is inspiring & Male & 23 & 2.1739 & .65033 & .13560 \\
\cline { 2 - 7 } & Female & 17 & 2.1765 & .63593 & .15424 \\
\hline $\begin{array}{l}\text { Sense of fulfilment after } \\
\text { completing the work }\end{array}$ & Male & 23 & 2.1304 & .75705 & .15786 \\
\cline { 2 - 7 } & Female & 17 & 1.8235 & .39295 & .09531 \\
\hline $\begin{array}{l}\text { Willing to accept all } \\
\text { sorts of challanges at } \\
\text { work }\end{array}$ & Male & 23 & 2.2174 & .73587 & .15344 \\
\cline { 2 - 7 } & Female & 17 & 1.8235 & .39295 & .09531 \\
\hline
\end{tabular}

Table 3

\begin{tabular}{|c|c|c|c|c|c|c|c|c|c|c|}
\hline & & \multicolumn{2}{|c|}{$\begin{array}{l}\text { Levene's Test for Equality of } \\
\text { Variances }\end{array}$} & \multicolumn{7}{|c|}{ t-test for Equaliy of Means } \\
\hline & & \multirow[b]{2}{*}{$\mathrm{f}$} & \multirow[b]{2}{*}{ Sig. } & \multirow[b]{2}{*}{$t$} & \multirow[b]{2}{*}{ df } & \multirow{2}{*}{$\begin{array}{l}\text { Sig. (2- } \\
\text { tailed) }\end{array}$} & \multirow{2}{*}{$\begin{array}{l}\text { Mean } \\
\text { Difference }\end{array}$} & \multirow{2}{*}{$\begin{array}{l}\text { Std. Error } \\
\text { Difference }\end{array}$} & \multicolumn{2}{|c|}{$\begin{array}{l}\text { 95\% Confidence Interval of } \\
\text { the Difference }\end{array}$} \\
\hline & & & & & & & & & Lower & Upper \\
\hline \multirow[t]{2}{*}{ Feel energetic at work } & $\begin{array}{l}\text { Equal variances } \\
\text { assumred }\end{array}$ & 2.209 & .145 & 1.516 & 38 & .138 & .37340 & .24632 & -.12525 & .87205 \\
\hline & $\begin{array}{l}\text { Equal variances not } \\
\text { assumed }\end{array}$ & & & 1.570 & 37.777 & .125 & .37340 & .23778 & -.10806 & .85486 \\
\hline \multirow[t]{2}{*}{ Job is insppiring } & $\begin{array}{l}\text { Equal variances } \\
\text { assumed }\end{array}$ & . 021 & .885 & -.012 & 38 & .990 & -.00256 & .20608 & -.41974 & .41463 \\
\hline & $\begin{array}{l}\text { Equal variances not } \\
\text { assumed }\end{array}$ & & & -012 & 35.060 & .990 & -.0256 & .20537 & -.41946 & .41434 \\
\hline \multirow[t]{2}{*}{$\begin{array}{l}\text { Sense of fulfiment after } \\
\text { completing the work }\end{array}$} & $\begin{array}{l}\text { Equal variances } \\
\text { assumed }\end{array}$ & 3.354 & .075 & 1.523 & 38 & .136 & .30691 & .20148 & -10098 & .71479 \\
\hline & $\begin{array}{l}\text { Equal variances not } \\
\text { assumed }\end{array}$ & & & 1.664 & 34.634 & .105 & .30691 & .18439 & -.06758 & .68139 \\
\hline \multirow{2}{*}{$\begin{array}{l}\text { Willing to accept all } \\
\text { sorts of challanges at } \\
\text { work }\end{array}$} & $\begin{array}{l}\text { Equal variances } \\
\text { assumed }\end{array}$ & 4.889 & .033 & 2.002 & 38 & .053 & .39386 & 19678 & -.00450 & .79223 \\
\hline & $\begin{array}{l}\text { Equal variances not } \\
\text { assumed }\end{array}$ & & & 2.181 & 35.072 & .036 & .39386 & .18063 & .02719 & .76053 \\
\hline
\end{tabular}

Table 4 


\begin{tabular}{|c|c|c|c|c|c|}
\hline & $\begin{array}{l}\text { Have you used Project } \\
\text { Management Systems? }\end{array}$ & $\mathrm{N}$ & Mean & $\begin{array}{c}\text { Std. } \\
\text { Deviation }\end{array}$ & $\begin{array}{l}\text { Std. Error } \\
\text { Mean }\end{array}$ \\
\hline \multirow{2}{*}{$\begin{array}{l}\text { Productivity increases } \\
\text { with the implementation } \\
\text { of technology in the } \\
\text { workplace }\end{array}$} & yes & 19 & 2.2632 & .65338 & .14989 \\
\hline & no & 21 & 1.9524 & .49761 & .10859 \\
\hline \multirow{2}{*}{$\begin{array}{l}\text { Technology helps in } \\
\text { meeting commitments } \\
\text { on time }\end{array}$} & yes & 19 & 2.3158 & .47757 & .10956 \\
\hline & no & 21 & 2.2857 & .64365 & .14046 \\
\hline \multirow{2}{*}{$\begin{array}{l}\text { Takes less time to } \\
\text { complete work with the } \\
\text { Implementation of } \\
\text { project management } \\
\text { software }\end{array}$} & yes & 19 & 2.2105 & .53530 & .12281 \\
\hline & no & 21 & 2.1905 & .40237 & .08781 \\
\hline
\end{tabular}

Table 5

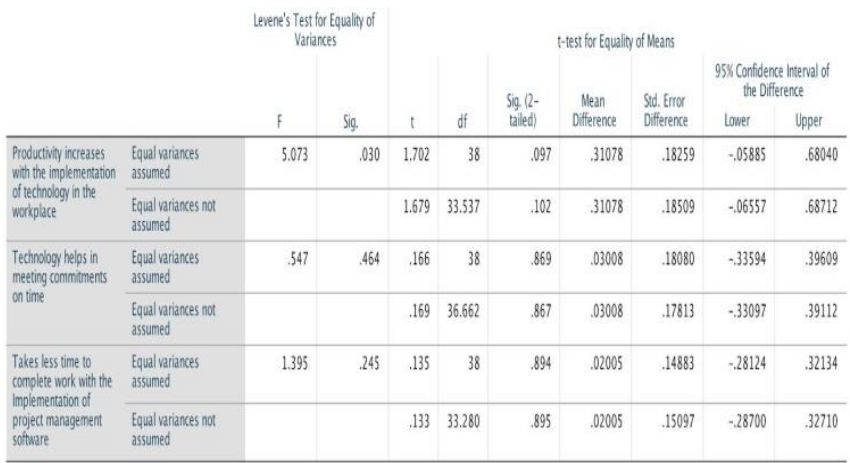

\section{DISCUSSIONS AND CONCLUSIONS}

It is undeniable that technology has become fashionable and there is external pressure, including from donors, to seek "the new trend". It is also undeniable that much of what is written about Technology comes from the innovation. Innovation is the first word in the Silicon Valley lexicon, accompanied by others such as "disruption", "human centred approach" and many other English terms that are hard to translate in a meaningful way to other contexts and languages. It's important to use an efficient project management system to help one stay organized while planning and executing projects. It is important for NGOs to start using software to manage projects, go for global change as well as stay connected with the help of digitalization. A lot of options are available in the market like project management software to specialized platforms for task management, accounting, image editing, file storage, time tracking, and more. It is quite cost effective.

The advent of information society has direct bearing upon the social and institutional environments in which NGOs operate. Being able to take advantages of ICTs in such a circumstance, NGOs expand dramatically their web of social interaction, increase its density, and promote new connections among diverse and dispersed social actors. They could solicit "wider participation" of citizens by locating people with far more ease than before who share same values and objectives with them, providing accessibility for those who are disabled, living in remote areas, and thus discouraged to join in policy process, and distributing information tailored for the interests of individual needs and aspirations. Increased participation serves as a source of political legitimacy for NGOs to identify social issues, raise dissident voices, develop alternatives and thus advocate and represent the interests of people. Such a role is particularly demanding since political agents could not aggregate, transmit, and represent the interests of principles with such accuracy and speed that they were expected to be due to increased turbulence of information flow and bureaucratic structure of government. NGOs could thus be considered as an 
alternative conduit for citizens to deliver their messages to government. They become essential to the vibrant functioning of a democracy. NGOs also become able to compete professionality and subject matter expertise with government officials since the monopoly or dominance of information by government could not be maintained any further in information society. Demarcation line between government and civil society becomes blurred and a tension to hold a sort of equilibrium between them takes place. NGOs become able to functionally complement or replace administrative agents, whose authority owes much to their professionality and accumulation of information, relying much on "deeper participation" of citizens. Magnitude of NGOs as a gatekeeper or a third party judge has upgraded.

\section{REFERENCES}

1. Stiroh K (2002) Information technology and the US productivity revival: what do the industry data say?

2. Weill P (1992) the relationship between investment in information technology and firm performance: a study of the valve manufacturing sector.

3. Menon, Rethy B. "Recent Trends In Industry In Adopting Crowdsourcing And Problem Solving For Employees Productivity And Efficiency With Special Reference To It Industry." International Journal of Mechanical and Production Engineering Research and Development. December (2017).

4. Dayan, M (2010) 'Managerial Trust and NPD Team Performance: Team Commitment and Longevity as Mediators' Journal of Business \& Industrial Marketing.

5. Kirkman, B. L., D. L. Shapiro. 1997. The impact of cultural values on employee resistance to teams: Toward a model of globalized self-managing work team effectiveness.

6. McAfee, A. 2002. The impact of enterprise information technology adoption on operational performance: An empirical investigation.

7. Non Profit Tech for Good. (2018). Global Ngo Technology report.

8. AL MOUZANI, I. M. A. N. E., and DRISS BOUAMI. "THE INTEGRATION OF LEAN MANUFACTURING AND LEAN MAINTENANCE TO IMPROVE PRODUCTION EFFICIENCY." International Journal of Mechanical and Production Engineering Research and Development (IJMPERD) 9.1 (2019): 593604.

9. Viswanath Venkatesh (2010). Impacts of Information and Communication Technology Implementations on Employees'Jobs in Service Organizations in India: A Multi-Method Longitudinal Field Study

10. Venkatesh, V., M. G. Morris, F. D. Davis, G. B. Davis. 2003. User acceptance of information technology: Toward a unified view.

11. Rousseau, D. M., Y. Fried. 2001. Location, location, location: Contextualizing organizational research.

12. Parasuraman, A., C. L. Colby. 2000. Technology Readiness Index(TRI): A multiple-item scale to measure readiness to embrace new technologies.

13. PRIYA, V. KRISHNA, and R. AMUTHA. "AN IMPACT OF TRAINING ON EMPLOYEE PRODUCTIVITY AND DEVELOPMENT." (2015).International Journal of Human Resource Management and Research (IJHRMR) 5. 5, Oct 2015, 4144.

14. ZeenobiyahNadiyahHannif, Anne Cox, Shamika Fernando (2014), The impact of ICT, workplace relationships and management styles on the quality of work life: insights from the call centre front line.

15. Das, SaritPrava, and Parna S. Mishra. "Antecedents and consequences of employee engagement: A critical analysis of literature review." International Journal of Human Resources Management 3.2 (2014): 7386. 
16. Pauleen, D and Yoong, P (2001) 'Relationship building and the use of ICT in boundary-crossing virtual teams: A facilitator's perspective' Journal of Information Technology.

17. Warkentin, M and Beranek, P(1999) 'Training to improve virtual team communication' Information Systems Journal. 